\title{
Diversity, Host Range and Distribution of Mistletoes along Steep Altitudinal Gradient of Tribhuvan Highway, Central Nepal
}

\author{
G.P. Joshi ${ }^{1}$ and M.P. Devkota ${ }^{2 *}$ \\ ${ }^{1}$ Laboratory of Plant Genetics, Graduate School of Agriculture, Kyoto University, Kyoto 6068502, Japan \\ $2^{2 *}$ Botany Department, Amrit Science Campus, PO Box 102, Tribhuvan University, Kathmandu, Nepal \\ E-mail: mdevkota@wlink.com.np
}

Received: 10.05.2009, Accepted: 25.09.2010

\begin{abstract}
A total of 11 mistletoe species, eight belonging to five genera in the family Loranthaceae and three species belonging to two genera in the family Viscaceae were documented from 43 host species belonging to 24 unrelated host families along Tribhuvan highway, central Nepal. Wide host range of Scurrula species (Loranthaceae) showed that they were more generalist and successfully parasitized as many hosts as encountered, while Viscaceae mistletoes showed narrow host range and high degree of host specificity since they infected a limited number of hosts. The irregular and patchy distribution of mistletoe along the highway was governed by three major factors: forest structure, site mesoclimate and availability of suitable host species. Marginal fragmented forests located along the warm sunny slopes of highway were found as most suitable habitat. Warmer southern sunny slopes, between Sinbhanjyang to Bahise Dobhan, favoured wider altitudinal distribution range of mistletoe compared to cold and moist northern slopes.
\end{abstract}

Key words: Mistletoe, diversity, host range, distribution, microclimate, Nepal

\section{Introduction}

Mistletoes are a polyphyletic group of plants and have been considered as highly specialized and most successful group of flowering parasitic plants due to their ability to exploit wide range of hosts. Mistletoes comprise approximately 1306 species (Nickrent, 2002) from a broad range of habitats across all continents except Antarctica (Kuijt, 1969; Calder, 1983; Calder and Bernhardt, 1983; Watson and Dallwitz, 1992). They are reported from a wide range of host plants ranging from forest trees to horticulture trees from Nepal (Devkota and Acharya, 1996; Devkota and Glatzel, 2005; Devkota and Kunwar, 2006).
Johri and Bhatnagar (1972) state that no trees and shrubs have immunity against mistletoe infestation and all of them are equally prone to their infection. Among all mistletoe families, Loranthaceae and Viscaceae have largest number of species ca.900 and ca.350, respectively (Nickrent, 2002).

Mistletoes have been reported from a wide range of hosts from all over the world and their greatest diversity is found in forests and woodlands (Kuijt, 1969; Calder, 1983; Hawksworth, 1983). In their extensive compilation list, Barney et al. (1998) reported 452 host species of 44 
families for Viscum album and Hawksworth et al. (1993) reported 401 known hosts of 77 families for Dendrophthoe falcata. Similarly, Devkota and Acharya (1996) reported 46 host species of 25 families from the Kathmandu Valley, Devkota and Glatzel (2005) reported 95 host species of 45 families from the Annapurna Region, and Devkota and Kunwar (2006) reported 69 host species of 38 families from GodawariPhulchowki area of the Kathmandu Valley.

Hawksworth (1959), Ganguly and Kumar (1976), Zakaullah and Khan (1982), Xiao and $\mathrm{Pu}$ (1988) concluded that temperature and sunlight are the main environmental factors governing mistletoe distribution as they are commonly recorded from warm and sunny areas. Lopez et al. (2002) reported that fragmented forest edges are better habitats for mistletoe growth, similar to the observations of Kuijt (1964). Mistletoe growth on isolated trees in fragmented forests is favored not only because of increased light but also because of the preferences of many seed disseminating birds for such a kind of habitat. In Kuijt's (1964) observations distribution of mistletoe is limited by environmental factors and is not related to a specific host, which is conflicting with Abulfatih and Emara (1988) observation on host specificity. Devkota and Glatzel (2005) concluded that forest structure, site mesoclimate and zoochoric dispersal are the major determining factors in the distribution of mistletoes in the Annapurna region of Nepal. Kuijt (1969) gives more importance to the bird's behaviour and conclude that distribution entirely depends upon the habits of the birds disseminating the seeds.

Mistletoe diversity from Nepal Himalaya is still incomplete therefore, present study attempts to explore mistletoe diversity, host range and distribution patterns along Tribhuvan Highway in central Nepal. The results of the study will be supplement information on Nepalese mistletoe diversity and will also add inputs for their conservation.

\section{Materials and methods}

The study was carried out along Tribhuvan Highway as it provided a great diversity of vegetation types ranging from sub-tropical to upper cool temperate types which changed with elevation and climate on the northern and southern slopes of Mahabharat Mountain range. The inventory was started at Naubise located on northern slope at 945 $\mathrm{m}$ and ended at Bhaise Dobhan located on southern slope at $926 \mathrm{~m}$, covering a total distance of $97 \mathrm{~km}$ in Makawanpur district in central Nepal. The highest point of the highway passes through Sim Bhanjyang $(2518 \mathrm{~m})$ and lies in upper cool temperate region (Fig. 1). Sim Bhanjyang area receives snow fall during winter and temperature drops below $0^{\circ} \mathrm{C}$ for about 10 days whereas Naubise and Bhaise Dobhan experience hot and humid conditions with temperature rising above 35 degrees during summer.

Naubise study area was dominated by agricultural land and patches of remnant forests of sub tropical region represented by Alnus nepalensis, Schima wallichii and Castanopsis indica, and orchards. At the highest elevation near Daman and Sim Bhanjyang Pinus wallichiana, Rhododendron arboreum and various Oak species, such as Quercus semecarpifolia, $Q$. lamellose, and $Q$. lanata, dominated the vegetation. In contrast, lower temperate and subtropical region in the southern slope was 
G.P. Joshi and M.P. Devkota / Our Nature (2010) 8: 106-117

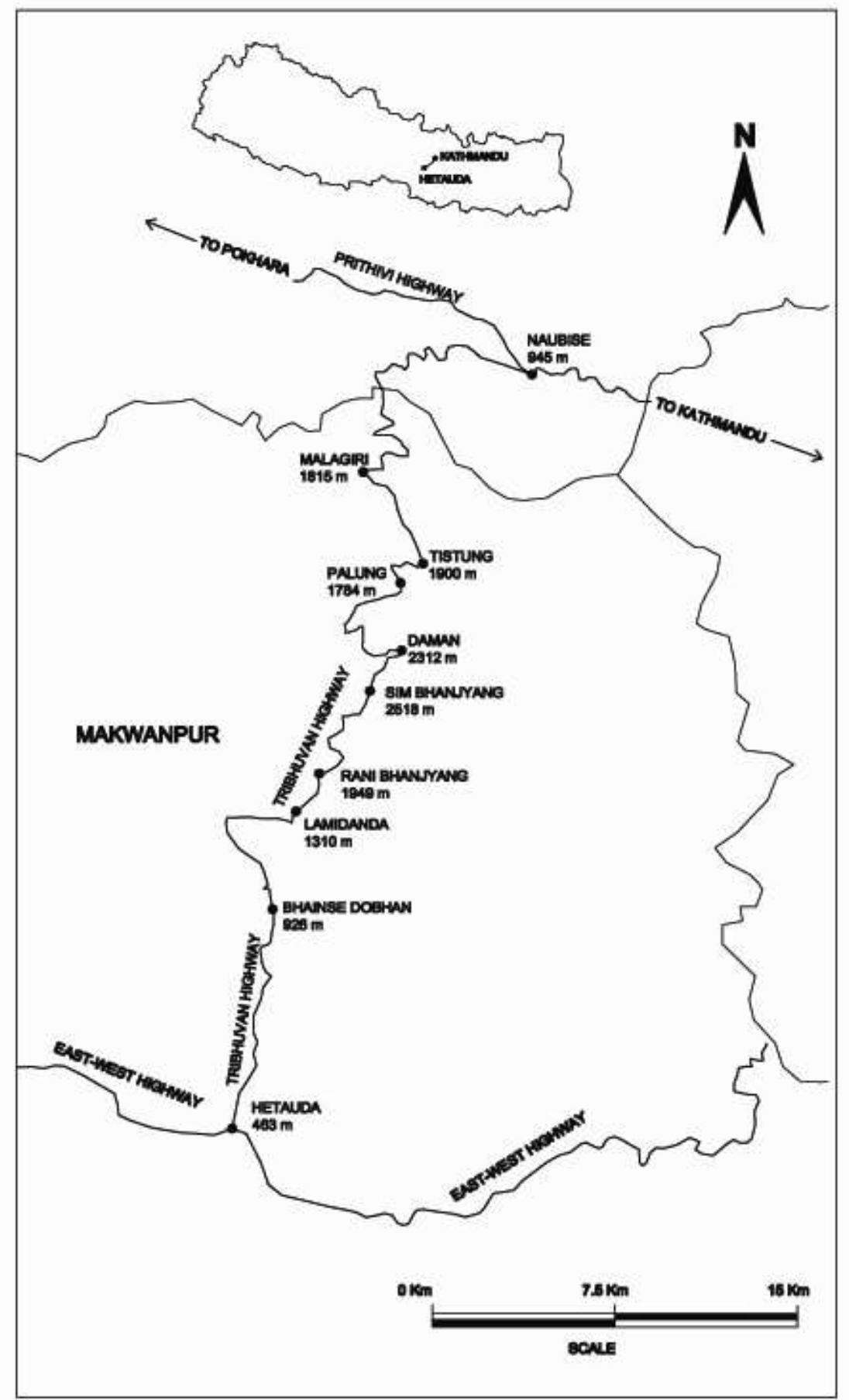

Figure 1. Study area. 
represented by Pinus roxburghii, Montane Hill Sal forest (Shorea robusta) and Mixed Broad-leaved forest.

The study was focused to cover a wide altitudinal area for the mistletoe inventory along Tribhuvan Highway. Therefore, the representative areas of various vegetation types were visited extensively to explore mistletoe diversity and host species. Forest trails developed by local people were used to cover maximum possible area for the inventory representing different forest types at different elevations. Undisturbed to moderately disturbed forests and degraded marginal forests along with planted forests; orchards and vegetations surrounding agricultural fields were also visited for this purpose. Necessary consultation was also sought with the Daman Botanical Garden and local people during inventory. Occurrence of all mistletoe species were recorded with their respective hosts along with the ecological circumscription of habitat such as altitude, slope direction, availability of light and moisture, forest type, and their condition during the inventory.

Standard sized mistletoe specimens were collected carefully without endangering their local population, and herbariums were prepared (Devkota and Glatzel, 2005). Collected mistletoe specimens were identified with the help of available herbariums deposited at KATH and confirmed with the help of field notes and other standard literature. Identification of host plants was based on Hara et al. (1978-1982), Malla et al. (1976), Koba et al. (1994), and Press et al. (2000). The international Plant Name Index (http://www.ipni.org) was accessed for the taxonomic nomenclature of mistletoe and host species.

\section{Results and discussion Vegetation composition along the highway} Naubise $(945 \mathrm{~m})$ to Simbhanjyang $(2518 \mathrm{~m})$ (Northern slope)

Most of the natural forest along this segment of highway has been exploited by the local people and at present it is dominated by farmlands and orchards at lower elevations. Scattered remnant patches of Schima-Castanopsis forest are found up to $1500 \mathrm{~m}$. Eroded areas and gullies are dominated by Alnus nepalensis. Forest becomes much denser above $1500 \mathrm{~m}$ and is dominated by Rhododendron arboreum, Lyonia ovalifolia, and Alnus nepalensis associated with Myrica esculenta, Coriaria nepalensis, Maesa chisia, Berberis aristata etc. Pure forest of Pinus wallichiana dominates the area around Daman at 2300 $\mathrm{m}$. Other associated plant species found at this elevation are Rhododendron arboreum, Lyonia ovalifolia and Quercus semecarpifolia with Gaultheria fragrantissima as a dominant shrub. At Simbhanjyang the vegetation is dominated by Quercus semecarpifolia, $Q$. lanata, $Q$. lamellosa and Rhododendron arboreum with Lyonia ovalifolia, Neolitsia pallens, Pieris formosa and Viburnum erubescence as associated species.

Simbhanjyang to Bhaise Dobhan (926 m) (Southern slope)

While descending from Simbhanjyang, Pinus wallichiana is completely replaced by broad leaved forest. This segment of highway has much dense forest dominated by various species of Quercus such as $Q$. semecarpifolia, Q. lamellosa, and Q. lanata 
with Rhododendron arboreum, $R$. lepidotum, Lyonia ovalifolia, Betula alnoides, Alnus nepalensis and Neolitsia pallens up to $2000 \mathrm{~m}$. Further below up to $1400 \mathrm{~m}$, vegetation is dominated by $Q$. lanata and Schima wallichii with Viburnum erubescence and Maesa chisia as dominant shrub. Schima-Castanopsis forest reappears in scattered patches where the slopes are sunny and much warmer. At further lower elevation the vegetation is represented by Montane Hill Sal Forest (Shorea robusta), Pinus roxburghii, and Wendlandia sps. No $R$. arboreum and $M$. chisia are found below $1300 \mathrm{~m}$ toward Bhaise Dobhan where Shorea robusta becomes the dominant tree species.

\section{Mistletoe diversity and host range}

A total of eleven mistletoe species, eight belonging to five genera in the family Loranthaceae and three species of mistletoes belonging to two genera in the family Viscaceae were recorded along the Tribhuvan Highway, parasitizing 43 host species belonging to 32 genera in 24 unrelated families (Tab. 1). The results of mistletoe inventory showed similarity with that of previous inventories conducted by Devkota and Glatzel (2005) and Devkota and Kunwar (2006) in Annapurna and Godawari-Phulchowki Areas, respectively. Genus Scurrula was largest having four species within the family Loranthaceae.

Compared to family Viscaceae, family Loranthaceae had a much wider host range and was recorded from 41 host species (Tab. 2). Within the family Loranthaceae, Scurrula species had most number of host species showing generalist pattern, an observation consistent with Barlow (1991), Devkota and Acharya (1996) in Kathmandu Valley, and Devkota
(2003) in Annapurna area. The narrow host range of Viscaceae mistletoes showed a high degree of host specificity as they were recorded from a limited number of hosts of few families despite their occurrence in a heterogeneous host community similar to the result of Devkota (2003). The narrow host range of Viscaceae mistletoes from the study area could be due to the results of feeding behavior of dispersers as suggested by Kuijt (1969).

A wide range of host species reported from the study area showed similarity with Ganguly and Pal (1975), Hawksworth et al. (1993) and Pundir (1995) for Loranthaceae mistletoes.

\section{Distribution}

The distribution of mistletoes in natural plant communities is affected by various factors as a result their distribution is never uniform. Especially the microclimatic factors like temperature, exposure to sunlight, and moisture play a significant role in their distribution (Devkota and Glatzel, 2005; Devkota and Kunwar, 2006). Mistletoes were recorded more commonly from the marginal forests, roadsides and partially disturbed habitats all along the highway showing consistency with the findings of Ganguly and Kumar (1976), Lopez et al. (2002) and Devkota and Glatzel (2005). Common occurrence of mistletoes in marginal forests was probably due to suitable habitats provided for mistletoe birds that are important disperser and pollinator species (Ladley and Kelly, 1996). Distribution of mistletoes along the highway was found to have rather patchy distribution due to the availability of suitable host species that keeps on changing with altitude (Devkota and Acharya, 1996). Mistletoes were rarely recorded from dense, moist and undisturbed forests as they do not 
provide suitable habitats for mistletoe bird species.

Occurrence of Berberis aristata, Rubus ellipticus, Viburnum erubescence and $V$. mullaha in fragmented marginal forest areas, as invasive shrub species, also increase the suitability of the habitat for mistletoe birds by providing an alternate source of food as observed in previous studies by (Devkota and Glatzel, 2005; Devkota and Kunwar, 2006). It was found that such fragmented forests in mixed broad- leaved forest located between 1000 to $2000 \mathrm{~m}$ elevations are better habitats for mistletoes.

Altitude is also one of the important factors in determining the distribution pattern of mistletoes in natural plant communities as shown by the previous studies in different parts of Nepal by Devkota and Glatzel (2005) and Devkota and Kunwar (2006). Distribution of Dendrophthoe pentandra was confined between 900 to $1300 \mathrm{~m}$ on both northern and southern slopes of the study area as the distribution of its suitable host species Schima wallichii was also confined between this elevations. Macrosolen cochinchinensis and Scurrula pulverulenta also showed similar pattern as their hosts were found only on the northern slopes of the study area. Scurrula gracilifolia was distributed at lower elevation in northern slope but was recorded at higher elevation on southern slope due to the distribution pattern of its host species. Visccaceae mistletoe showed the similar pattern of distribution associated with their host species. Except Viscum multinerve (Viscacae), which parasitizes on Shorea robusta, other Viscaceae mistletoes were confined at higher elevation due to the distribution of their hosts.

There was not much difference in the diversity of mistletoe species on northern and southern slopes but compared to northern slope, mistletoes were distributed over a wide altitudinal range on southern slope. Viscum multinerve was absent in the north slope but had nearly $1000 \mathrm{~m}$ altitudinal distribution range due to the presence of its suitable host species (Tab. 3) and favorable microclimatic conditions on the southern slope (Fig. 3). Taxilus vestitus also showed similar pattern and had a wide altitudinal distribution range on the southern slope due to common occurrence of various Oak species as its suitable host (Fig. 3). Similar distribution pattern was shown by Scurrula gracilifolia and Dendrophthoe pentandra. Interestingly Scurrula elata did not show any variation in its distribution pattern on either slope. It was observed that suitable microclimatic conditions and availability of host species over a wide altitudinal range have favored the distribution of mistletoes over a wide area on southern slope (Fig. 3) similar to the previous observation of Devkota and Acharya (1996) in Kathmandu valley and Devkota and Glatzel (2005) in Annapurna Area. On the northern slope mistletoe species showed much narrow altitudinal distribution range due to unfavorable microclimatic condition having longer cold and moist conditions throughout the year and also due to less availability of common host species as a result of human influence on the local vegetation (Fig. 2).

Scurrula species were recorded from a wide range of host species. This observation gives a clear indication that Scurrula species have the ability to exploit both forest and domesticated plant species and are more successful in establishing itself on a wide range of host species in various types of habitats. 
G.P. Joshi and M.P. Devkota / Our Nature (2010) 8: 106-117

Table 1. Mistletoe species and their host range (survey 2007).

\begin{tabular}{lccc}
\hline Mistletoes species & $\begin{array}{c}\text { Host species } \\
\text { (No) }\end{array}$ & $\begin{array}{c}\text { Host genus } \\
\text { (No) }\end{array}$ & $\begin{array}{c}\text { Host family } \\
\text { (No) }\end{array}$ \\
\hline Dendrophthoe pentandra (L.) Miquel & 2 & 2 & 2 \\
Loranthus odoratus Wall. & 1 & 1 & 1 \\
Macrosolen cochinchinensis (Lour.) Van Tiegh & 2 & 2 & 2 \\
Scurrula elata Danser & 19 & 16 & 12 \\
Scurrula gracilifolia (Schult.) Danser & 11 & 9 & 8 \\
Scurrula parasitica L. & 4 & 3 & 3 \\
Scurrula pulverulenta G. Don & 14 & 11 & 9 \\
Texillus vestitus Danser & 6 & 3 & 3 \\
Korthalsella japonica (Thunberg) Engler & 1 & 1 & 1 \\
Viscum articulatum Burm. f. & 2 & 2 & 2 \\
Viscum multinerve Hayata & 3 & 3 & 3 \\
\hline
\end{tabular}

Table 2. Host species of Loranthaceae and Viscaceae families (survey 2007)

\begin{tabular}{lccc}
\hline Mistletoe & \multicolumn{3}{c}{ Host } \\
\cline { 2 - 4 } family & Species & Genus & Family \\
\hline Loranthaceae & 41 & 30 & 22 \\
Viscaceae & 5 & 4 & 4 \\
Total & 43 & 32 & 24 \\
\hline
\end{tabular}

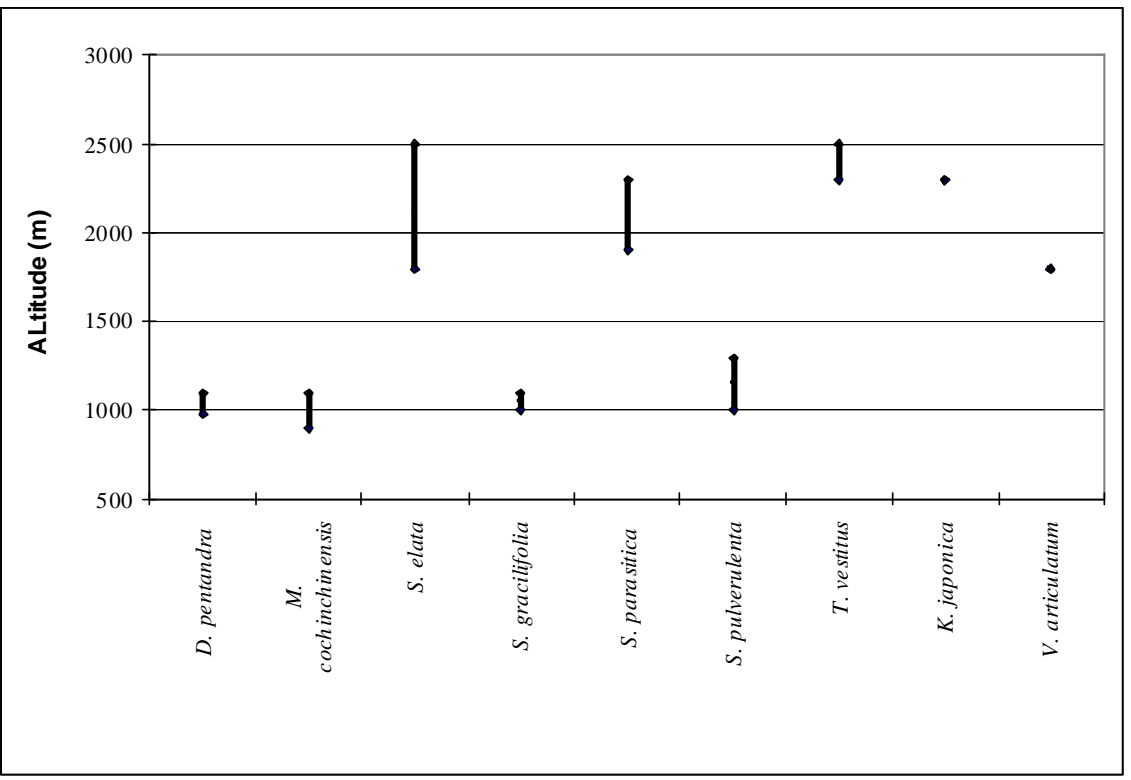

Figure 2. Occurrence and altitud inal distribution of mistletoes on northern slope. 
G.P. Joshi and M.P. Devkota/ Our Nature (2010) 8: 106-117

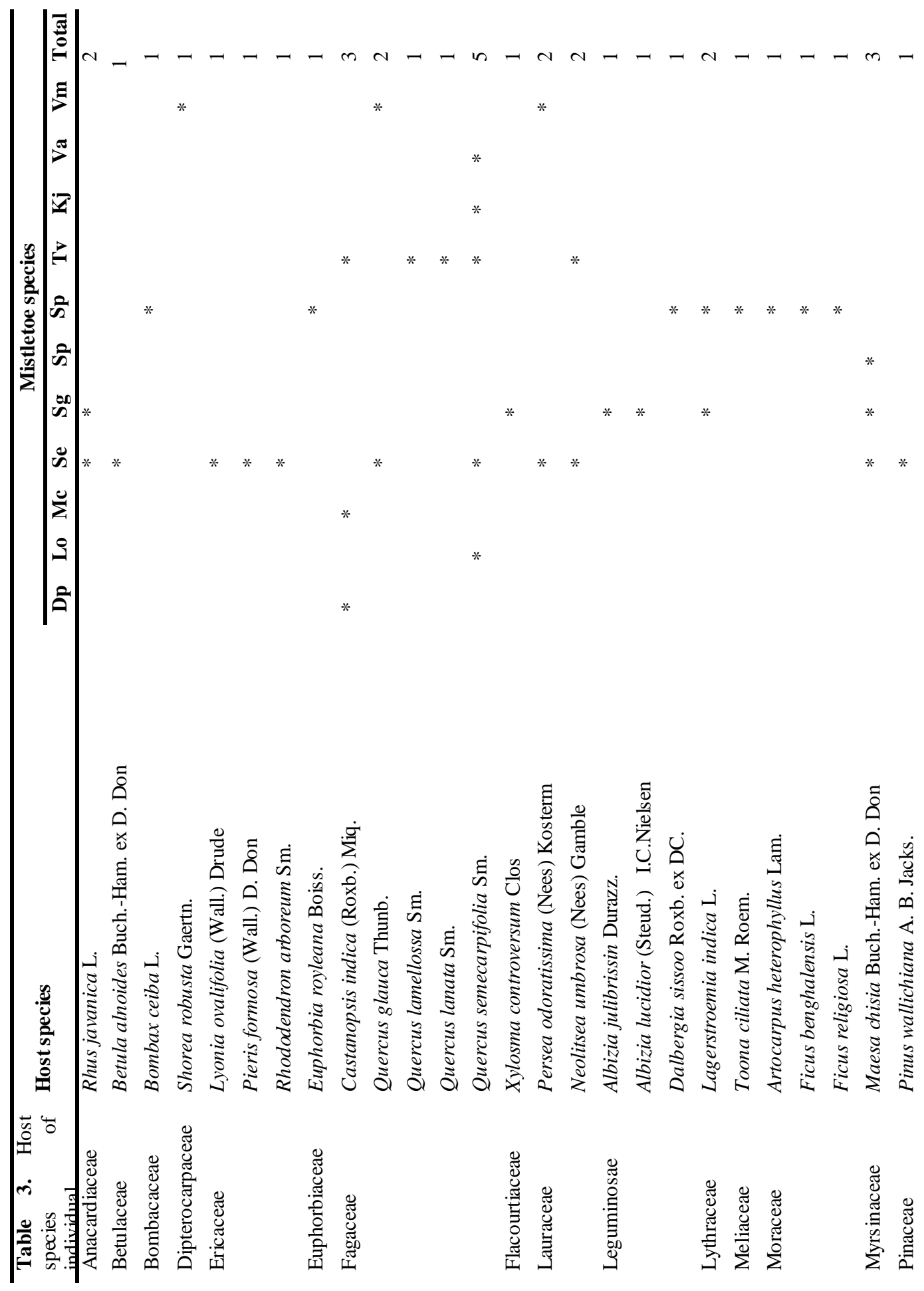


G.P. Joshi and M.P. Devkota / Our Nature (2010) 8: 106-117

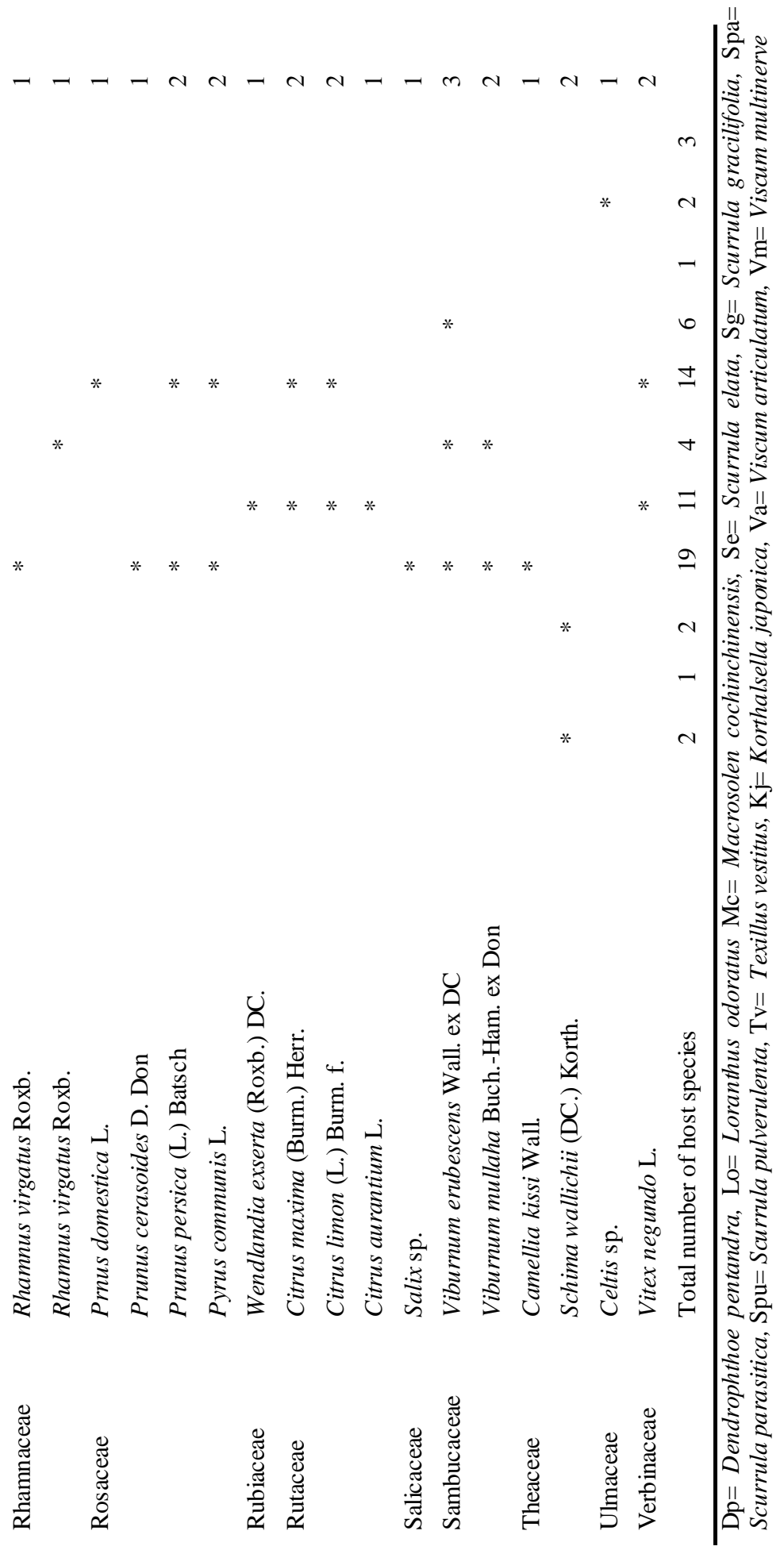




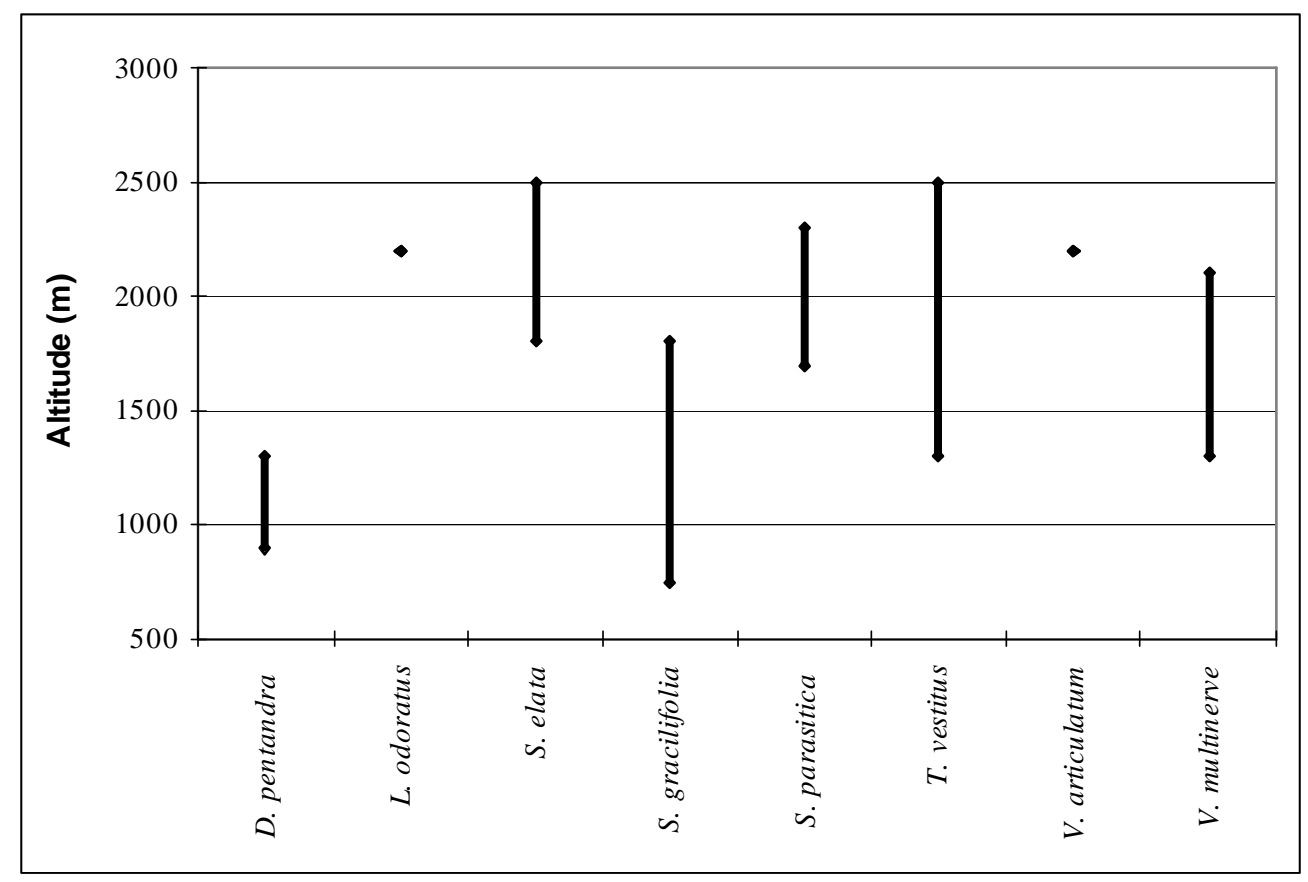

Figure 3. Occurrence and distribution of mistletoes on southern slope.

Based on mistletoe diversity and their occurrence few potential mistletoe habitats have been identified in entire study area. First one is Naubise (northern slope) and its surrounding area having common occurrence of Dendrophthoe pentandra, Macrosolen cochinchinensis and Scurrula pulverulenta, and the second one is Daman, Simbhanjyang and Aghor areas with common occurrence of $S$. parasitica, $S$. elata and Texillus vestitus. These areas provide suitable microclimatic condition and abundance of host species favoring the mistletoe growth.

Regarding the host specificity of mistletoe some general patterns became visible from the present investigation. Few mistletoe species showed permanent association of high preferences towards certain hosts. Dendrophthoe pentandra showed high specificity towards its host Schima wallichii between 1000-1300 m in Naubise area however, infestation decreased with increasing altitude as the host number decreased. Similarly, Texillus vestitus was observed commonly occurring on various Quercus species above $2000 \mathrm{~m}$ showing high specificity. Scurrula elata showed low specificity, a pattern consistent with the findings of Barlow (1991) and Devkota and Glatzel (2005). The remarkable association of Scurrula elata with Rhododendron arboreum and Lyonia ovalifolia at $2000 \mathrm{~m}$ was an indication of high preferences towards these two hosts. As in other parts of Nepal reported by Devkota and Acharya (1996), Devkota and Glatzel (2005) and Devkota and Kunwar (2006) Viscaceae 
mistletoes showed high degree of specificity since they were recorded only from few hosts.

\section{Acknowledgement}

The University Grants Commission, Kathmandu, Nepal is duly acknowledged for supporting the study.

\section{References}

Abulfatih, H.A. and H.A. Emara 1988. Altitudinal distribution of the hemiparasitic Loranthaceae in South Western Saudi Arabia. Biotropica 20: $81-83$

Barlow, B.A. 1991. Conspectus of the genera Scurrula L. and Taxillus Teigham (Loranthaceae). Blumea 36: 63-85.

Barney, C.W., F.G. Hawkworth and B.W. Geils 1998. Hosts of Viscum album. Eur. J. Forest Pathol. 28: 187-208.

Calder, M. 1983. Mistletoes in focus: An introduction. In The biology of Mistletoes (Eds. M. Calder and P. Bernhardt), Academic Press. Australia. pp. 1-18.

Calder, M. and P. Bernhardt 1983. The biology of parasitic flowering plants. Academic Press Australia. 348 p.

Devkokta, M.P. 2003. Mistletoes of the Annapurna Conservation area of the central Nepal Himalayas- diversity, distribution and biology. University of Natural Resources and Applied Life Sciences, Vienna. 159 p. (Ph.D. Thesis)

Devkota , M.P. and G. Glatzel 2005. Mistletoes of the Annapurna Conservation area of the central Nepal Himalayas. J. Jap. Bot. 80: 27-36.

Devkota, M.P. and N. Acharya 1996. Mistletoes (Loranthaceae and Viscaceae) in the Kathmandu valley, Nepal: Altitudinal distribution, host trees, pollinators and seed dispersers. Acta Phytotaxon. Et Geobot. 47(2): 213-219.

Devkota, M.P. and R.M. Kunwar 2006. Diversity, distribution and host range of Mistletoes in Godawari-Phulchoki area, Kathmandu, Nepal. J. Jap. Bot. 81: 255-261.
Ganguly, P. and D. Pal 1975. Some notes on the distribution, nature of hosts and symptoms of a flowering parasite, Macrosolen cochinchinensis in West Bengal. J. Bomb. Nat. Hist. Soc. 72: 883-886.

Ganguly, P. and N.C. Kumar 1976. Topographical distribution of the phanerogamic parasites in Sukna forest, Darjeeling district, West Bengal. Ind. Forester 102: 459-462.

Hara, H., W.T. Stearn and L.H.J. Williams 1978. An enumeration of the flowering plants of Nepal. Vol. I. British Museum (Natural History), London.

Hara, H., W.T. Stearn and L.H.J. Williams 1979. An enumeration of the flowering plants of Nepal. Vol. II. British Museum (Natural History), London.

Hara, H., W.T. Stearn, A.O. Chater and L.H.J. Williams 1982. An enumeration of flowering plants of Nepal. Vol. III. British Museum (Natural History), London.

Hawksworth, F.G. 1983. Mistletoes as Forest Parasites. In The biology of Mistletoes, (Eds. M. Calder and P. Bernhardt), Academic Press. Australia. pp. 317-333.

Hawksworth, F.G., Y.P.S. Pundir, C.G. Shaw and B.W. Geils 1993. The host range of Dendroepthoe falcata (L.f.) Etttings (Loranthaceae). Ind. J. Forestry 16(3): 263281.

Hwakswoth, F.G. 1959. Distribution of dwarf mistletoes in relation to topography on the Mesacalaro Apache reservation, New Mexico. Ind. J. Forestry 57: 919-922.

Johri, B.M. and S.P. Bhatnagar 1972. Loranthaceae: Botanical monograph No.8. Council of Scientific and Industrial Research, New Delhi, India.

Koba, H., S. Akiyama, Y. Endo and H. Ohba 1994. Name list of the flowering plants and gymnosperms of Nepal. The University Museum, the University of Tokyo, Tokyo.

Kuijt, J. 1964. Critical observation on the parasitism of new world mistletoes. Can. J. Bot. 42: 1243-1287.

Kuijt, J. 1969. The biology of parasitic flowering plants. University California Press. Los Angeles. $246 \mathrm{p}$. 
G.P. Joshi and M.P. Devkota / Our Nature (2010) 8: 106-117

Ladley, J.J. and D. Kelly 1996. Dispersal, germination and survival of New Zealand mistletoes (Loranthaceae): dependence on birds. New Zealand J. Ecol. 20: 69-79.

Lopez De Buen, L., J.F. Ornelas and J.G. Garcia Franco 2002. Mistletoe infection of trees located at fragmented forest edges in the cloud forests of entral Veracruz, Mexico. Forest Ecol. and Management 164: 293-302.

Malla, S.B., A.B. Shrestha, S.B. Rajbhandary, T.B. Shrestha, P.M. Adhikari and S.R. Adhikari 1976. Catalogue of Nepalese vascular plants. Bulletin of Department of Medicinal Plants Nepal, No. 7, Dept of Med. Plants. Ministry of Forest. HMGN/N.

Nickrent, D.L. 2002. Mistletoe phylogenetics: Current relationships gained from analysis of DNA sequences. In The Proceedings of the Western International Forest Disease Work Conference, Waikoloa, Hawaii. pp. 48-57.
Press, J.R., K.K. Shrestha and D.A. Sutton 2000. Annotated checklist of the flowering plants of Nepal. The Natural History Museum, London.

Pundir, Y.P.S. 1995. Host range of Scurrula pulverulenta (Wall.) G. Don. Loranthaceae from Dun valley and adjacent areas. Ind. J. Forestry 18: 74-79.

Watson, L. and M.J. Dallwitz 1992 onwards. The families of flowering plants: Description, illustrations, identification and information retrieval. Version: $14^{\text {th }}$ December 2000. http://biodiversity.uno.edu/delta/

Xiao, L., Z. Pu 1988. An exploration of the Loranthaceae in Xishuanghanna. Acta Bot. Yunnan. 10: 69-78.

Zakaullah and M.H. Khan 1982. Survey and control of mistletoes in Pakistan. Pakistan Forest Institute, Peshawar, Annual Technical Report. Project PK-FS-55.11. 